\title{
Cidade, arte e criação social: novos diagramas de culturas juvenis da periferia
} GLÓRIA DIÓGENES ${ }^{I}$

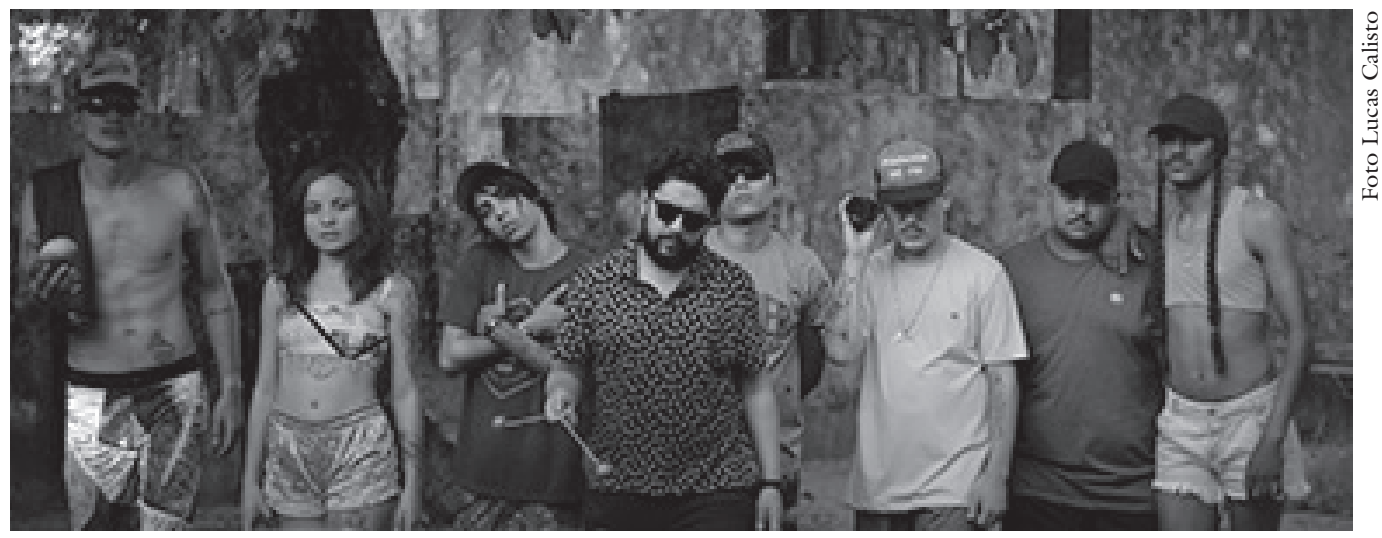

Fonte: Catarse.

Figura 1-A Convocação. ${ }^{1}$

\section{Os bastidores: quando a palavra é gesto}

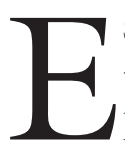

STE ARTIGO pretende narrar linhas de encontros, atuações, diálogos, participações cruzadas, colaborações entre jovens moradores das periferias de Fortaleza, realizadas por meio de uma extensiva pesquisa antropológica. ${ }^{2}$ Ao longo de experiências de investigação acadêmica encetadas há mais de duas décadas, no âmbito das práticas e das culturas juvenis, ${ }^{3}$ pude intuir que seguir caminhos, partilhar espaços de convivência, de produção de eventos, estar em shows, exposições, saraus, exibições torna-se por vezes mais rico do que a edição prévia de um mapa em que o pesquisador pré-define os sítios da pesquisa, seus instrumentos e técnicas. ${ }^{4}$

Ao invés de tomar variáveis explicativas e generalizantes tais quais a juventude, a cidade, assim como Agier (2011, p.59), pude observar que os conhecimentos da antropologia urbana emergem de uma sequência de "montagem da vida urbana, retiradas de uma ínfima parte do curso real do mundo". Decidi, assim, no esteio de outros antropólogos urbanos, traçar uma rota metodológica que se esboça no curso de uma geografia que se refaz, continuamente, e transmuda o objeto da análise.

Por meio de uma investigação que vem sendo desenvolvida junto com pesquisadores do Laboratório das Artes e das Juventudes (Lajus), ${ }^{5}$ acerca da 
produção das artes de rua em Fortaleza,${ }^{6}$ diferentes sequências de encontros, de trocas foram se sucedendo no âmbito dos cenários juvenis. Observo que, muito embora estudos apontem, cada vez mais, a ampliação de índices da denominada juventude "nem, nem, nem" (não estuda, nem trabalha, nem pretende voltar a trabalhar e estudar), ${ }^{7}$ paradoxalmente, identifica-se um incremento de experiências juvenis criativas, ${ }^{8}$ que emergem de vivências de rua e que acontecem, no geral, sem a mediação de agentes "externos" ou sem o protagonismo direto deles.

Entre paisagens materiais e digitais, ${ }^{9}$ práticas culturais de origem diversa, de variadas estéticas e linguagens, têm mobilizado múltiplos fazeres juvenis; tais quais a organização de saraus, as produções audiovisuais realizadas por meio de celulares, a formação de coletivos de arte, a inserção em grupos de teatros de rua, dentre tantos outros. Contrariando caminhos normativos mediados pela via institucional ${ }^{10}$ escola/trabalho e sob um efeito de "táticas desviacionistas" (De Certeau, 2000), ${ }^{11}$ essas juventudes parecem condensar signos inventariados pelas mídias com repertórios concernentes a jeitos e linguagens pactuados nas culturas de rua..$^{12}$ Nesse sentido, este artigo pretende discorrer, tomando como caso exemplar a produção de um selo audiovisual da periferia denominado $V e$ tinflix, acerca de novos diagramas de invenção e de criatividade de juventudes contemporâneas.

No âmbito das culturas de rua, uma "Fortaleza Cromática" aponta para fios diversos de experiências, balizados pela ligação dos jovens com o território, pela formação de coletivos, por esquemas de autoprodução e publicização de imagens, narrativas e audiovisuais. Vale ressaltar que a maior parte dessas iniciativas é de natureza autoral, registrada com selos "independentes", sendo seus próprios produtores os responsáveis pela difusão e circulação dos conteúdos. São incontáveis as ações que, em Fortaleza, expressam essa pluralidade de práticas e enlace de coletivos juvenis.

Um dos exemplos exponenciaais diz respeito à destacada proliferação, na capital do Ceará, de saraus de periferia. Neles confluem poesia, literatura, leitura dramática, vídeos-poemas, assim como convergem outras iniciativas e manifestações artísticas e culturais. No geral, são reunidos, em um evento de sarau, cantores, performers, atores de práticas circenses, $\mathrm{MC},{ }^{13}$ roqueiros, rappers, dançarinos e instrumentistas de maracatu, atores de teatro, fotógrafos; crianças, adolescentes, jovens, adultos e idosos.

Em Fortaleza, os saraus se multiplicam, ${ }^{14}$ assumindo a força do que poderíamos denominar "guerrilha poética". "Microfone aberto" (Silva, 2019), as práticas poéticas não apenas movem o dia a dia de bairros diversos das periferias, como suscitam o eco de seus versos em paragens distintas. O Porto Iracema das Artes, espaço de formação e difusão artística e cultural do governo do estado do Ceará, ofereceu um curso de formação que resultou no zine literaturas periféricas, com a "compilação de imagens, diário de bordo, publicação marginal e estêncil, registros das narrativas dos alunos sobre a cidade e seus habitantes". 
O curso, do Programa de Fotopoéticas da Escola, teve como facilitadores os artistas Rômulo Silva, Gustavo Costa e Leo Silva, sendo Rômulo um dos idealizadores e porta-voz do denominado Sarau da Bl. ${ }^{15}$

Mas nem tudo é poesia. Vozes inspiradoras, por meio de gritos em verso e prosa, acabam por denunciar violações diárias de direitos e ações arbitrárias impetradas pela polícia às juventudes de espaços vulnerabilizados. O enfrentamento cotidiano às facções, ${ }^{16}$ às "exclusões" escolares, a quase inacessibilidade ao mundo do trabalho, a imposição do contumaz silêncio, o inaudível de seus desejos e demandas emergem de vozes juvenis em rimas e métricas. Têm sido corriqueiras, sob o pretexto da busca de drogas, de armas, num visível espetáculo de "sujeição criminal", ${ }^{17}$ ocorrências de agressões, censuras, emprego de táticas de terror da polícia às sessões de saraus. ${ }^{18}$ Dentre outros, o sarau Levante pela Paz é interrompido com um "aparato de guerra". ${ }^{19}$

Palavras e imagens, em forma de poesia, literatura, ${ }^{20}$ de teatro de rua, ${ }^{21}$ da produção audiovisual têm mobilizado o cotidiano de jovens das periferias. Como diz Piúba $(2019$, p.3), "existe uma topografia poética que está sendo descrita na superfície das periferias de Fortaleza". Ocorre uma espécie de reescrita de histórias periféricas que, até então, haviam sido contadas por outros, na maior parte das vezes por pesquisadores, por jornalistas, por especialistas em estudos e análises sobre a pobreza, ficando, no geral, as juventudes na condição de informantes e narradores de pesquisa.

Emergem outras palavras. Uma escrita, como diz Flusser (2010, p.20), que, além de um gesto reflexivo, que se volta para o interior, é também um gesto (político) que se volta para o exterior. Atuam os atores dos saraus, nas diversas práticas poéticas, como se as palavras fossem gestos, formas de agir, formas de intervir. Microfones abertos produzem assim novas imagens e imaginários no espetáculo das variadas cenas urbanas juvenis. ${ }^{22}$

\section{Imagens em ação: humor, irreverência e improviso}

Nove de novembro de 2019, Praia de Iracema, Fortaleza, mais exatamente na parte da orla que se convencionou denominar "praia dos crush". Ocorre ali um evento significativo. Em torno de cinco mil jovens, na sua maioria moradores da periferia da cidade, se reúnem para assistir ao lançamento do primeiro episódio de uma série denominada La Casa du'z Vetin, ${ }^{23}$ produzida pelo recém-criado selo audiovisual Vetinflix. Essa cena exemplar condensa múltiplos fios de significados.

O primeiro é a presença de um traço cultural característico do que se costuma denominar Ceará Moleque, relativo à irreverência, ao humor e à comédia. O próprio nome da série ratifica o "cearencês", ${ }^{24}$ qual seja, um conjunto de expressões próprias do povo do Ceará. Dados históricos indicam que isso vem de longe. O "espírito moleque", como frisa Otacílio de Azevedo (apud Ponte, 1993, p.175), referindo-se à sua vivência em Fortaleza entre 1910 e 1930, podia emergir em razão de qualquer evento jocoso, qualquer cena passível de sátira, exagero ou "quebra" da normalidade. 
Alia-se ao espírito moleque um segundo aspecto, vinculado à produção do seriado-sátira La Casa d'uz Vetin, aquilo que, como bem ressalta Pais (2012, p.17), aponta para um tipo de prática colaborativa, tecida no âmbito de uma nova criatividade relacional, em que prevalece "uma cooperação entre modos de pensar e fazer, um jogo de astúcias e audácias que coloca em estado de sítio a normatização". O uso das redes sociais como lugar de fluxo, de combinação de atores e variáveis "distantes" promove o surgimento de talentos peculiares, produz habilidades que escapam à regulação do tempo e à normatividade do mundo do trabalho. Trata-se daquilo que Hannerz (2015, p.295), ao discutir acerca da construção das cidades e da vida urbana, indica como sendo ela, a fluidez, o vetor de "lubrificação para a maquinaria das carreiras" e inovação de papéis. Um exemplo destacado pelo autor é a notória gangue Manson na Califórnia do final da década de 1960. Ele, Manson, havia entrado e saído de instituições de "correção" desde os primeiros anos de adolescência. Segundo Hannerz (2015, p.298), era ele um dos indivíduos capazes "de transformar antigas experiências em um novo papel" no "mundo das amalgamações culturais".

Trata-se de sujeitos que aprenderam, na "escola da vida", a se virar, a se desdobrar, a enfrentar "corres" de natureza diversa e dar conta de múltiplas destrezas e, assim, a empreender diversificadas tarefas. Tal qual indicou a pesquisa acerca da "Geração N" (Diógenes, 2019), "o trampo ${ }^{25}$ no que rolar" evidencia o malabarismo constante que permeia suas vidas, tendo em vista que esses sujeitos "se equilibram entre os ritos da profissionalização e as rotas da criatividade" (Diógenes, 2019, p.57). Vale ressaltar que, mesmo dando seus "pulos", se desdobrando em diferentes atividades, essa juventude que nem estuda nem trabalha dilata as estatísticas dos que estão fora do mercado de trabalho e dos bancos escolares. No ziguezague entre "diásporas de desespero" e "diásporas de esperança", esses jovens movimentam "a força da imaginação" (Appadurai, 1996, p.17) e afirmam que, diante da falta de oportunidade de um trabalho ${ }^{26}$ formal, desejam mesmo é poder desenvolver projetos. ${ }^{27}$

É assim que Léo, morador da denominada Quadra 10 do residencial Euclides Gomes, no Bairro Jangurussu, ${ }^{28}$ construído pelo projeto "Minha Casa, Minha Vida", ${ }^{29}$ se inspira a criar, junto com outros jovens, o Suricate ${ }^{30}$ e o La Casa du'z Vetin, de um lugar, como ele mesmo destaca, que nem $\mathrm{CEP}^{31}$ tem. Em uma conversa nossa com vários jovens do residencial, que se estendeu por toda uma tarde de sábado, Léo observa que, na concepção dos que formam o Suricate e dos que integram o seriado, "o imaginário tem que tá ligado ao território, porque todo mundo que mora na periferia sabe disso, pra sobreviver, meu chapa, tem que jogar o jogo que eles jogam". Marcado pelo conflito ${ }^{32}$ e pela ocupação de facções, ${ }^{33}$ por disputas internas pelo controle das unidades habitacionais, segundo Léo, nesse lugar

[...] os meninos jogam bola, os menino brincam de polícia e ladrão e os menino gravam vídeo pra internet, porque é a brincadeira que quando é 
noite, que desligou as luzes, eles pegam o celular da mãe ou dos amigos e vão ficar assim ó tudo gravando, interpretando cada um a sua história, o que quiser, o mundo contado a partir da visão deles também.

Cria-se assim, num território inóspito, fora dos códigos de endereçamento, aquilo que Appadurai (1996, p.22) vai denominar práticas culturais de todos os dias, por meio das quais se transformam e se multiplicam o que o autor designa "obras da imaginação". Passam elas a ter, no mundo pós-eletrônico, ainda seguindo as trilhas de Appadurai (1996, p.17), um significativo papel, saindo a imaginação do singular "espaço expressivo da arte, mito e ritual, para passar a fazer parte da atividade mental cotidiana [...]". Por meio da partilha da senha do $W i-F i$ da rede de Léo, muitos dos "vetin" do residencial podem produzir suas páginas nas redes sociais, partilhar suas histórias no Instagram $^{34}$ e fazer circular imagens do bairro e de práticas e de si.

O terceiro aspecto que o encontro dos Suricates com a Nigéria, produtora do seriado, faz suscitar diz respeito a uma certa torção na construção da linguagem, de demarcação e publicização do jeito de falar dos jovens da periferia. No cenário que abre o primeiro episódio, os "vetin" enunciam, na projeção do ano 2049, o advento da "vetincracia". O "novo" panorama demarca o prólogo, momento em que os "vetin" chegam ao poder e anunciam o inimigo, aqueles que não parecem se conformar com o domínio dos que vêm das periferias, os PA (Playboys da Aldeota ${ }^{35}$ ). Observa-se a escolha do uso de uma linguagem coloquial, como já assinalado, do escárnio e do deboche em detrimento do emprego correto da língua portuguesa. A expressão $d^{\prime} u z_{z}$ ao invés de dos, configura essa "quebra" com os ritos da escrita codificados nos ditames da gramática.

A conjunção de todos esses aspectos, mais que uma manifestação do vetor isolado da criatividade, destaca, como profere De Certeau (2000, p.94), a expressão de outras maneiras de fazer, "de utilizar a ordem imposta do lugar ou da língua. Sem sair do lugar de onde tem que viver e que lhe impõe uma lei, e aí instaura uma pluralidade e uma criatividade. Por uma arte de intermediação de efeitos imprevistos". Esses efeitos imprevistos modulam o "rumor da língua" (Barthes, 1988, p.124), revelam a possiblidade de se dizer uma coisa de várias maneiras, fazem dimanar "uma guerra da linguagem", que "produz-se onde a sociedade transforma a diferença em conflito".

Os "vetin", durante os três episódios lançados ${ }^{36}$ até então, insistem em evidenciar o dia a dia dos jovens nas periferias, a intensidade das ações policiais, a força das facções na regulamentação e o trânsito entre jovens no bairro e entre bairros. $\mathrm{O}$ palavreado usado no seriado por seus atores é quase um dialeto para o público desavisado. Neles, a linguagem se contorce, enverga-se, recria-se em "táticas" (Certeau, 2000) que produzem outros dispositivos de fala. Pelo contrário, os "vetin" instituem dispositivos de elocução que agem e engendram esquemas de operações não facilmente capturáveis para quem desconhece o mundo Vetinflix, para quem se mantém longe das periferias. 
O seriado La Casa condensa signos diversificados das linguagens juvenis de periferia, aqueles que não costumam ter lugar nas escolas, nas instituições que promovem políticas públicas para juventudes, nos espaços instituídos de sociabilidade. Como aponta Yargo, já citado diretor do seriado, ${ }^{37}$ "os Vetin também têm cultura, como os Vetin também representam uma fortaleza, enfim, tudo isso é que na nossa visão traz esse potencial desruptivo na cultura que tem esse diferencial”.

Mais que uma linguagem, o que parece ensejar os "vetin" e o seu "potencial disruptivo", como sublinha Flusser (2014, p.16), é o esboço de um gesto, "movimento no qual se articula uma liberdade". Pois os episódios, que cada vez mais atraem a atenção de jovens não apenas das periferias, conduzem-se por um tom de insolência, até mesmo de chacota ao papel desempenhado pela polícia, diante das ações e ardis dos "vetin". É possível perceber que a trama não pretende que facilmente se decifre, para o observador e para quem assiste, "a liberdade que (nela) se exprime" (Flusser, 2014, p.16).

Os "influenciadores digitais", os atores e as atrizes que contracenam no seriado montam uma espécie de roteiro do improviso, como se o dia a dia da periferia, seus conflitos, suas dinâmicas de vida, se colocasse como o centro da paródia. Como destaca Tim Ingold (2012), tal qual "emaranhados criativos num mundo de materiais", cada fio do seriado faz parte do enredo, dos lugares do bairro, ${ }^{38}$ dos artefatos usados pelos "vetin" (incluindo apitos, revólveres de plástico, celulares etc.), das vestimentas, dos jogos de linguagem, das brincadeiras, das danças; tudo isso se associa à dinâmica do repentino, do que acontece e que, no seriado, volta a ocorrer, gerando uma espécie dobra ${ }^{39}$ do mesmo acontecimento.

O "vetin", na qualidade de artista, "atua como um itinerante, e seu trabalho comunga com a trajetória de sua vida" (Ingold, 2012, p.38). O espectador, também, foge do papel de mero observante, ele é convocado a coabitar as cenas, assim como é invitado a atuar como cofinanciador do seriado e, consequentemente, como coprodutor da Vetinflix. Ocorre aquilo que Didi-Huberman (2017), em um texto que trava um instigante diálogo com Harun Farocki, ${ }^{40}$ denomina de "devolver a imagem". Nessa perspectiva, indica Didi-Huberman (2017, p.206), "é preciso instituir os restos: tomar nas instituições o que elas não querem mostrar - o rebotalho, o refugo, as imagens esquecidas ou censuradas - pra retorná-las a quem tem de direito, à comunidade, aos cidadãos".

Um outro aspecto, e talvez seja o ponto alto desse entrançado de variáveis que permeia a construção dessa experiência fílmica, diz respeito à correlação entre a circulação e o uso de imagens na paisagem digital e a difusão dos episódios da série. Movidos pela "montagem" de ideias e de "imagens sobreviventes", vindas de múltiplos lugares e de diversos influenciadores digitais, os "vetin" acabam produzindo uma ressemantização dos processos de produção e apropriação de imagens, ao difundirem modalidades de práticas juvenis e repertórios 
de enfretamento à polícia, às facções e aos contumazes estigmas perfilados pelas instituições. Deixam de aparecer, na qualidade, meramente, de juventude "nem, nem, nem", ${ }^{42}$ protagonistas das páginas policiais, sujeitos de risco e de ameaça à ordem pública, e projetam-se na condição de artistas, termo citado em todas as descrições de perfil do Instagram dos participantes do seriado.

Por fim, no deslindar das principais variáveis que atravessam o La Casa $d u ' z$ Vetin, narro aqui um caso curioso que pude presenciar na projeção do primeiro episódio, ocasião do Seminário Cada Vida Importa, ${ }^{43}$ ocorrido no Instituto Cultural Iracema, órgão ligado à prefeitura de Fortaleza. Estávamos na Praia de Iracema, cercados por gestores, professores, jovens de projetos de ONG, militantes de direitos humanos, dentre outros. Talmon Lima (31 anos), "vetin" e um dos idealizadores do seriado, se afasta do Centro Cultural e caminha em direção à praia, que se situa logo em frente à edificação. Rapidamente, vários policiais se aproximam e iniciam o baculejo. ${ }^{44}$ Talmon, que se identifica como humorista e atua nas redes sociais como Maycou Presly, costuma emitir um som peculiar com a boca, como se imitasse um pássaro. No momento da abordagem policial, ficamos todos tensos, mas logo Talmon disse "deixa, eu desenrolo". Indagado pela polícia sobre o que fazia, ele respondeu: "sou YouTuber". ${ }^{45}$

Aquilo pareceu à polícia um tipo de atrevimento, uma atitude de irreverência, uma desobediência. Como um jovem que, certamente, não seria identificado como um potencial morador de bairros nobres da cidade, seria alguém notável? Até que um policial pergunta: "e quem é você no Youtube?”. Talmon, de pronto, responde, "sou Maycou Presley". Então o policial olha incrédulo e diz: "pois faz aquele barulho com a boca". Ao emitir o som conhecido, característico, Talmon rapidamente é olhado com entusiasmo pelos policiais, e os gestos de violência se convertem em procedimentos de camaradagem e admiração. O chefe da operação mira os demais e diz: "deixa o cara ir, não é vagabundo não". E qual seriam as faces e as astúcias desses não "vagabundos" convertidos em artistas e influenciadores digitais?

A maioria da juventude que faz parte do seriado - Léo Suricate, ${ }^{46}$ Dudú Suricate, ${ }^{47}$ o Everton ${ }^{48}$ (Pokindeia), o Talmon Lima Humorista, ${ }^{49}$ o Rodolfo Rodrigo $^{50}$ (xero verde), as Princesas do passinho, ${ }^{51}$ o Pobretion, ${ }^{52}$ afora Moisés Lourenço (o personagem que encarna o professor) - tem em comum a construção de uma linguagem que se estabelece na periferia para as periferias. Isso afirma, também, para o restante da cidade, a "moral" de uma prática "roxeda", 53 que traz, para as mídias sociais, destacadamente para o YouTube e o Instagram, a vida, a linguagem, os "corres", as "tretas", ${ }^{54}$ as festas, a poesia e afetos que povoam e dinamizam a vida dos jovens nas grandes periferias das metrópoles.

\section{Aspectos conclusivos: espaço aberto para as próximas cenas}

De modo geral, observou-se, tanto no que se refere ao conjunto de narrativas pactuadas ao longo da pesquisa quanto em situações de observação direta da pesquisadora, uma direta correlação não apenas entre riso e escárnio, como 
também no que tange a duas variáveis que aparecem recorrentemente nas falas de Léo: a da artesania, qual seja, da coisa "mal feita", e a da "brincadeira". ${ }^{55}$

O improviso, aquilo é construído dentro do acontecimento, que foge à lógica de uma racionalidade abstrata, em que por vezes "se tem dificuldade em entender, em cheirar as linguagens sensíveis da vida cotidiana" (Pais, 2003, p.21), se transmuda em cada seriado na aventura coletiva da experimentação. Mal feito no que concerne a não estar pronto, acabado, como obra fechada. O rascunho, aquilo que mais parece uma brincadeira que um intento levado à sério, promove, entre os jovens que assistem ${ }^{56}$ ao seriado, uma espécie de sensação de coprotagonismo, de coparticipação, de cocriação, de obra em aberto.

Observou-se, também, em cada um dos episódios partilhados em público, uma qualidade do uso da caricatura, do exagero, mediado por uma dicções lúdicas, cômicas, que "brincam" com a suposta natureza ociosa dos "vetin", e a condição "perigosa", atribuída comumente aos jovens, nos cotidianos embates com a polícia. Isso diferencia, tal qual discutido no transcorrer deste artigo, no diálogo com Appadurai (1996), as distinções e as diluições de fronteiras entre "obras do trabalho" e "obras da imaginação". Essa aproximação entre diferentes obras, e aqui se concentrou o objetivo mais precípuo da escrita deste artigo, mostra que é no suposto mundo do "não trabalho", nas denominadas zonas de exclusão social, de esquecimento das políticas públicas de juventude, que móveis e misseis de fala poética, de imagens em bombardeio literário, de irreverentes produções fílmicas ensejam formas singulares de criação, de produção artística e de reinvenções de si e do mundo.

$\mathrm{Na}$ ampliada "máquina do sacrifício" (Agamben, 2007), que atravessa parte exponencial da juventude brasileira negra, pobre, moradora de periferia, de jovens que povoam as estatísticas "nem, nem, nem", que, por vezes, incorporam o epíteto de anormais $^{57}$ (sendo eles a maioria da população brasileira), as novas gramáticas visuais e poéticas aqui apresentadas agenciam formas singulares de profanação. Escapando de uma espécie de "museificação do mundo" (Agamben, 2007, p.73) como uma dimensão separada da existência, engessada em normatizações, esses jovens tomam o bairro, seus atores e vizinhos, como contracenantes de outras possibilidades, a de fazer valer imagens e falas de lugares inexistentes, sítios apagados dos códigos postais.

Diante de mecanismos de captura, de classificação, de massificação, essas juventudes produzem dispositivos de "contágio do profano", "um tocar que desencanta e devolve ao uso aquilo que pareceria separado e petrificado" (Agamben, 2007, p.66). Não seriam essas as linhas tortas de uma linguagem que gagueja, que se esquiva da gramática oficial e põe a "brincar" novos diagramas de criatividade das juventudes contemporâneas? 


\section{Notas}

1 Imagem captada no site Catarse. Disponível em: <https://www.catarse.me/lacasaduzvetin>. Acesso em: 23 maio 2020.

2 Desenvolvemos, desde 2014 (após um ano de pesquisa em Lisboa, no intercurso do estágio pós-doutoral), em Fortaleza, uma investigação sobre artes de rua. Ela tem seguido linhas de encontro. Como um ponteado de bordado, um fio enreda-se ao outro, entrecruza sujeitos e formas, produzindo um tipo de movimento etnográfico sem fronteiras definidas e desenho prévio de seus interlocutores.

3 Seguindo as considerações de Machado Pais (2003, p.69), "por cultura juvenil, em sentido lato, pode entender-se o sistema de valores socialmente atribuídos à juventude (tomada como conjunto de referido a uma fase da vida), isto é, a valores a que aderirão jovens de diferentes meio e condições sociais".

4 Trata-se, assim, de uma atividade de pesquisa com uma assumida "identificação subjetiva". Pais (2017, p.130), em um instigante artigo denominado "A captação do social e as armadilhas do método: aprendendo com Ruth Cardoso e seu jeito de ser", destaca que as experiências reflexivas vividas por observadores e observados assumem-se como uma condição da participação-ação. Dito assim, elas não dependem da vontade do pesquisador, mas perpassam todas as experiências que ocorrem no trabalho de campo.

5 Ligado ao Departamento de Ciências Sociais da Universidade Federal do Ceará.

6 Pesquisa atual, no desdobramento da mesma temática, financiada pelo CNPq, denominada "Fortaleza Cromática - Trajetórias, mapas e circuitos das artes urbanas".

7 Dados do Instituto de Pesquisa Econômica Aplicada (Ipea), de 2019, indicam que 23\% dos jovens não trabalham nem estudam (nem, nem). Disponível em: <https:// agenciabrasil.ebc.com.br/geral/notici a/2018-12/ipea-23-dos-jovens-brasileiros-nao-trabalham-e-nem-estudam>. Acesso em: 20 maio 2020.

8 Tim Ingold (2015, p.309), no livro Estar vivo, aponta, no diálogo com Paul Klee, a perspectiva da criatividade esboçando-se afora da dimensão do produto do que se realizou, da obra final, qual seja retrospectivamente "[...] a partir de um resultado na forma de um objeto novo $[\ldots]$ ”.

9 Já venho desenvolvendo uma série de publicações acerca da relação entre práticas juvenis que permeiam os ambientes digitais e presenciais, tais como: "Arte urbana, juventude e educação sentimental: entre a cidade e o ciberespaço (experiências etnográficas)" (Diógenes, 2013); “A arte urbana entre ambientes: dobras entre a cidade material e o ciberespaço" (Diógenes, 2015a); "Artes e intervenções urbanas entre esferas materiais e digitais: tensões legal-ilegal" (Diógenes, 2015b); "Entre cidades materiais e digitais: esboços de uma etnografia dos fluxos da arte urbana em Lisboa" (Diógenes, 2015c); "Graffiti, escritos urbanos entre a cidade material e digital: o que anda a dizer Lisboa?" (Diógenes, 2015d); "Conexões entre artes de rua, criatividade e profissões: circuitos e criações de Tamara Alves" (Diógenes, 2019).

10 Sposito (1996, p.166), em artigo quase profético acerca da "sociabilidade juvenil e a rua", publicado em 1996, já apontava que, em um contexto de mudança e crise, "adquirem um relevo fundamental as dimensões socializadoras do mundo da rua".

11 A Invenção do Cotidiano I: as artes de fazer (De Certeau, 2000).

12 Considero cultura de rua as iniciativas que emergem de experiências, encontros e 
partilhamentos que têm a rua como palco, e a cidade como lugar de ação coletiva, na qualidade do que De Certeau (2000) denomina espaço praticado.

13 Como são chamados os Mestre de Cerimônias (MC), expressão que, comumente, designa os que fazem e difundem músicas ligadas ao rap (ritmo e poesia) e ao movimento hip-hop organizado. Para saber mais sobre o tema, consultar o livro Cartografias da cultura e da violência-gangues, galeras e o movimento hip hop (Diógenes, 1998).

14 O livro recém-lançado (Silva, 2019) pela Secretaria de Cultura do Estado do Ceará, denominado Ruma - poemas de saraus, organizado por Talles Azigon, reúne 20 poetas, que participam de diferentes eventos da cidade. Como diz Rômulo Silva (2019, p.97), no texto final da antologia, "os poetas inventam a palavra aberta como ato de sobrevivência".

15 O Sarau da Bl tem esse título porque acontece na Praça da Avenida Bulevar 1, n. 121, no Conjunto São Cristóvão, Grande Jangurussu.

16 No artigo intitulado “'Aqui não tem gangue, tem facção’: as transformações sociais do crime em Fortaleza, Brasil”, Paiva (2019, p.167) assinala ser o crime também "uma maneira de fazer o cotidiano e a cidade por meio da ação coletiva de pessoas envolvidas de maneiras diferentes em coletivos reconhecidos, socialmente, como 'facções'”.

17 Segundo Misse (2008, p.10), a sujeição criminal é especificamente esse processo por meio do qual um cidadão incriminado é constituído publicamente como um não homem, em que o criminoso é transformado em bandido, isto é, num tipo social cuja afinidade com outros tipos e camadas sociais está estabelecida no tempo de longa duração de nossa história.

18 Disponível em: <https://bemblogado.com.br/site/policia-interrompe-sarau-em-fortaleza-por-mera-suposicao/>. Acesso em: 10 maio 2020.

19 "O que nós vimos foi um aparato de guerra, inclusive com a Tropa de Choque, Cavalaria da Polícia Militar e o Corpo de Bombeiros”, conta Miguel Braz, da coordenação nacional do Levante Popular da Juventude”. Disponível em: <https://www.brasildefato.com.br/2019/04/01/em-fortaleza-aparato-de-guerra-interrompe-sarau-organizado-pelo-levante>. Acesso em: 10 maio 2020.

20 Atualmente, Fortaleza tem funcionando em torno de doze bibliotecas comunitárias, "[que] geralmente são construídas, organizadas e mantidas pelas comunidades onde estão instaladas". Disponível em: <https://tribunadoceara.com.br/noticias/educacao/saiba-onde-encontrar-bibliotecas-comunitarias-em-fortaleza/>. Acesso em: 27 maio 2020 .

21 Os principais grupos são Teatro de Caretas, Grupo As 10 Graças de Palhaçaria, Coletivo Os Pícaros Incorrigíveis, Nóis de Teatro, Trupe Caba de Chegar, além de artistas que se auto identificam como independentes, circenses e perfomers que também atuam na rua, mas não são grupos de teatro de rua.

22 Uma alusão ao livro de Helena Abramo (1994) denominado Cenas juvenis - punks e darks no espetáculo urbano.

23 Vetin advém do diminutivo de pivete. Os episódios são inspirados no seriado espanhol La Casa de Papel, que teve sua primeira produção em 2 de maio de 2017. Trata-se de um grupo de nove ladrões, liderados por um Professor, que prepara o roubo do século na Casa da Moeda da Espanha, com o objetivo de fabricar o próprio dinheiro em quantidades incalculáveis e nunca vista. Há uma visível analogia: "na produção de 
comédia cearense, um grupo de ex-alunos são convocados por um antigo professor de história (Moisés Loureiro na trama, o "Fêssor"), que os convida a participar de um grande golpe na Cidade. Um plano tão mirabolante quando o de 'La Casa de Papel', mas com questões relacionadas ao Ceará. Um grande golpe feito no Ceará”, comenta Yargo Gurjão, diretor da série e integrante do coletivo Nigéria. Disponível em: <https://gl.globo.com/ce/ceara/noticia/2019/11/07/serie-cearense-la-casa-duz-vetin-tem-estreia-neste-sabado-na-praia-dos-crush-em-fortaleza.ghtml>. Acesso em: 17 maio 2020.

24 Foi lançado, em 2002, o Orélio Cearense - Dicionário Romanceado e Ilustrado de Termos e Expressões do Palavreado do Ceará, da autoria de Andréa Saraiva. Na apresentação do livro, encontra-se uma breve explicação do teor do dicionário: "O encontro da história oral com a escrita, através do humor, irreverência e molecagem[,] fortalece e pede passagem para o Orélio Cearense chegar e ficar vivo e feliz nos corredores dos nossos caminhos urbanos e rurais" (Saraiva, 2002, p.1).

25 Os termos e expressões "trampar”, “fazer uns corres”, "se desdobrar”, “dar seus pulos" apareceram, recorrentemente, na citada pesquisa sobre Geração N, como nominações alternativas e diferenciadas da categoria trabalho e ocupação professional.

26 Essa foi uma das variáveis significativas que emergiram tanto no âmbito dos dados qualitativos quanto no dos dados quantitativos concernentes ao relatório da pesquisa Geração N.

27 Diz Appadurai (1996, p.14) que, "graças a multiplicidade de formas que assume (cinema, televisão, computadores e telefones) e à maneira rápida como se move no seio das rotinas da vida quotidiana, a comunicação electrónica é uma ferramenta para que cada indivíduo se imagine como um projecto social e curso".

28 De acordo com dados da prefeitura de Fortaleza, o IDH do Jangurussu é um dos mais baixos $(0,172)$, sendo que os considerados bairros nobres atingem índices bem mais elevados. O Meireles aparece com 0,953, e a Aldeota, com 0,867. Embora não se tratando de dados atualizados, esses índices expressam a paisagem de extrema desigualdade e concentração de renda que se desenha nessa metrópole. Disponível em: <https://www.fortaleza.ce.gov.br/noticias/prefeitura-apresenta-estudo-sobre-desenvolvimento-humano-por-bairro>. Acesso em: 20 maio 2020.

29 Trata-se de um programa de habitação federal do Brasil, de construção de edificações populares, lançado em março de 2009 pelo governo Lula.

30 O Suricate Seboso foi criado por dois jovens da periferia de Fortaleza em 2012; segundo esses jovens a página exibida em várias plataformas digitais pretende levar pra internet a linguagem e a cultura do povo cearense e nordestino com muito humor. No YouTube, a página crida em dezembro de 2013 já alcança 119.244 .235 visualizações. Disponível em: <https://www.youtube.com/user/SuricateOficial/about>. Acesso em: 26 maio 2020 .

31 Código de Endereçamento Postal. Isso, segundo Léo, limita, dentre outros aspectos, o acesso à internet, tendo em vista que a contratação da empresa é dificultada devido à não localização do Residencial.

32 Disponível em: <https://tribunadoceara.com.br/videos/jornal-jangadeiro/sonho-da-casa-propria-vira-pesadelo-para-beneficiarios-do-minha-casa-minha-vida/>. Acesso em: 27 maio 2020. 
33 Cinquenta e duas famílias foram expulsas do residencial por meio da ação de facções entre janeiro e julho de 2018. Disponível em: <https://tribunadoceara.com.br/videos/jornal-jangadeiro/faccoes-criminosas-ameacam-ate-criancas-ao-expulsar-familias-de-casa/>. Acesso em: 27 maio 2020.

34 Trata-se de uma rede social de fotos para usuários de Android e iPhone.

35 A Aldeota, além de ser um bairro nobre de Fortaleza, é, comumente, sinônimo de território de concentração de riqueza e de privilégios. Há quem diga que houve um processo de Aldeotização na metrópole, em que os bairros do entorno insistem em se identificarem como Aldeota, como forma de produção de prestígio e distinção social.

36 O primeiro é $A$ convocação, o segundo é $O$ plano, e o terceiro é $A$ Revelação.

37 O Coletivo Nigéria é a produtora responsável pelo seriado, junto com todos os outros jovens que participam do processo de criação e filmagem.

38 Quase todo o seriado foi filmado no Residencial Euclides Ferreira Gomes e em suas áreas de entorno.

39 Utilizo a categoria teórica “dobra” no diálogo com Deleuze (1991), mais especificamente em sua obra "A Dobra: Leibniz e o Barroco". A “dobra”, ao invés de aludir à duplicidade, sinaliza um fio de multiplicidades. Para Leibniz, "o múltiplo não é o que tem muitas partes, mas o que é dobrado de muitas maneiras” (Deleuze, 1991, p.46). Atuando na qualidade de um espaço contíguo de representações, a dobra não possibilita discernir onde acaba o espaço configurado e onde se iniciam os perímetros de um outro espaço.

40 Harun Farocki (1944-2014) produziu um conjunto de pensamentos e práticas sobre o trabalho com imagens e palavras. Comumente identificado como um cineasta-pensador. criou, entre o final da década de 1960 e o início de 2010, um tipo de metodologia de produção fílmica em que o cineasta deixava o filme pensar. "O que se busca é sempre uma composição de imagens/palavras que possibilite que o espectador seja incitado a desvelar o filme, efetivamente: ative um fluxo de atenções e pensamentos por imagens; por composição ou discurso visual. Essa parece ser a motivação maior de Farocki. As palavras ou comentários do filme, caso as tenham, em grande ou pequena medida, estarão sempre em sintonia com a composição de imagens. Em outras palavras, imagens e palavras estarão em um plano de horizontalidade" (Genaro, 2016, p.118). Nessa perspectiva, o espectador não é mero observador. Ele sempre exibia, antes da produção final, seus filmes para uma plateia que corroborava com a versão final de película, produzindo um tipo de antropologia da restituição. Isso significa dizer "[que] dar antes de qualquer troca [...] é dar sem reter, sem resto, sem interesse, sem capital, sem processo de apropriação ou expropriação" (Didi-Huberman, 2017, p.211).

41 Referência à obra de Didi-Huberman (2013) A imagem sobrevivente: história da arte e tempo dos fantasmas segundo Aby Warburg.

42 Vale ressaltar que, em uma publicação do Ipea, os autores apontam que a condição “nem, nem, nem" ocorre tendo em vista que "muitos jovens [...] não estão investindo em sua capacidade produtiva por meio do sistema formal de ensino ou diretamente no mercado de trabalho" (Costa; Ulyssea, 2014, p.115). É como se o próprio jovem acabasse sendo responsabilizado por sua esquiva em relação à escola e ao trabalho.

43 Instituído na Assembleia Legislativa do Ceará, em 2015, mais exatamente no Comitê 
Cearense pela Prevenção de Homicídios na Adolescência (CCPHA), esse movimento liderou várias pesquisas que abordam essa temática.

44 Termo utilizado para se referir à revista policial de jovens da periferia.

45 Página de Talmon Lima no Youtube. Disponível em: <https://www.youtube.com/ channel/UCcwrkgAHDx_1GON6cAc5XUQ>.

46 Disponível em: <https://www.instagram.com/leosuricate/?hl=pt-br>, com $21.2 \mathrm{mil}$ seguidores.

47 Disponível em: <https://www.instagram.com/dudusuricate/?hl=pt-br>, com 28 mil seguidores.

48 Disponível em: <https://www.instagram.com/evertoncassiol/>, com 239 mil seguidores.

49 Disponível em: <https://www.instagram.com/talmonlima/>, com 136 mil seguidores.

50 Disponível em: <https://www.instagram.com/rodolforodrigues_/>, com 18.9 mil seguidores.

51 Disponível em: <https://www.instagram.com/princesinhasdopassinho/>, com 8.182 seguidores.

52 Disponível em: <https://www.instagram.com/pobretion/>, com 217 mil seguidores.

53 Gíria constantemente usada pelo grupo, quer dizer aquilo que gera impacto positivo, que é "massa"; consiste também numa expressão-força de autoafirmação dos jovens das periferias.

54 Gíria usada para designar brigas, conflitos, disputas.

55 No texto "Conexões entre artes de rua, criatividade e profissões: circuitos e criações de Tamara Alves", Diógenes reforça a centralidade da variável brincadeira no curso das produções juvenis contemporâneas, no que se pode identificar como experiências de profissionalização. "As divisas entre o tempo da fruição da vida e o relativo ao domínio do trabalho cada vez mais se estreitam no âmbito das práticas e profissões consideradas criativas - aquilo que Pais (2012, p.161), no diálogo com Schutz, vai denominar de 'o mundo dos materiais lúdicos e dos pequenos brincadores', ao pesquisar o universo dos produtores de quadrinhos. A brincadeira surge como camarim de ensaio, ensejo para que o caos revele linhas legíveis nos esboços sucessivos do emprego dos sonhos" (Diógenes, 2019, p.172). Disponível em: <https://www.scielo.br/pdf/ha/ v25n55/1806-9983-ha-25-55-153.pdf>. Acesso em: 19 maio 2020.

56 Estive no lançamento do episódio 2, O Plano, no Centro Cultural Bom Jardim, na presença de mais de 100 jovens e crianças que moram no bairro e nas adjacências. Cada um se comportava como se as cenas que se desenrolavam dissessem respeito a eles e às suas vidas.

57 Assim se Michel Foucault (2002, p.69) se refere, em livro homônimo, aos “indivíduos a serem corrigidos". 
Referências

ABRAMO, H. W. Cenas Juvenis - punks e darks no espetáculo urbano. São Paulo: Escrita, 1994.

AGAMBEN, G. Profanações. São Paulo: Boitempo, 2007.

AGIER, M. Antropologia da cidade: lugares, situações, movimentos. São Paulo: Terceiro Nome, 2011.

ALMEIDA, M. I. M. de; PAIS, J. M. Apresentação. In: ALMEIDA, M. I. M. de; PAIS, J. M. (Org.) Criatividade, juventude e novos horizontes profissionais. Rio de Janeiro: Zahar, 2012. p.7-20.

APPADURAI, A. Dimensões culturais da globalização. Lisboa: Teorema, 1996.

AZIGON, T. (Org.) Ruma - poemas de saraus. Fortaleza: Secretaria de Cultura do Estado do Ceará, 2019.

BARTHES, R. O rumor da língua. São Paulo: Brasilense, 1988.

BENEVIDES, M. A produção de si pelo trabalho: estratégias, práticas e experiências juvenis. Fortaleza, 2019. Tese (Doutorado em Sociologia) - Programa de Pós-Graduação em Sociologia, Universidade Federal do Ceará.

COSTA, J. S. de M.; ULYSSEA, G. O fenômeno dos jovens Nem Nem. In: CORSEUIL, C. H.; BOTELHO, R. U. (Org.) Desafios à trajetória profissional dos jovens brasileiros. Rio de Janeiro: Ipea, 2014.

DE CERTEAU, M. de. A invenção do cotidiano I: artes de fazer. Petrópolis: Vozes, 2000.

DELEUZE, G. A Dobra: Leibniz e o Barroco. Campinas: Papirus, 1991.

DIDI-HUBERMAN, G. A imagem sobrevivente: história da arte e tempo dos fantasmas segundo Aby Warburg. Rio de Janeiro: Contraponto, 2013.

Devolver uma imagem. In: ALLO, E. (Org.) Pensar a imagem. Belo Horizonte: Autêntica, 2017.

DIÓGENES, G. Cartografias da cultura e da violência: gangues, galeras e o movimento hip hop. São Paulo: Annablume, 1998.

Cartografias da cultura e da violência: gangues, galeras e o movimento hip hop. 2. ed. São Paulo: Annablume, 2008.

Juventudes, violência e políticas públicas no Brasil: tensões entre o instituído e o instituinte. Sinais Sociais, Rio de Janeiro, v.6, n.18, p.102-23, jan./abr. 2012.

. Arte urbana, juventude e educação sentimental: entre a cidade e o ciberespaço (experiências etnográficas). Linguagem, Educação e Sociedade, Teresina, v.1, n.18, p.5176 , ago. 2013.

Jovens, mídias e redes sociais na internet: subjetividades contemporâneas. In: CARRANO, P.; FÁVERO, O. Narrativas juvenis e espaços públicos. Rio de Janeiro: Editora da UFF, 2014.

. A arte urbana entre ambientes: "dobras" entre a cidade "material" e o ciberespaço. Etnográfica, Lisboa, v.19, n.3, p.537-56, 2015 a.

. Artes e intervenções urbanas entre esferas materiais e digitais: tensões legal-ilegal. Análise Social, Lisboa, v.4, n.217, p.682-707, 2015b. 
DIÓGENES, G. Entre cidades materiais e digitais: esboços de uma etnografia dos fluxos da arte urbana em Lisboa. Revista de Ciências Sociais, Fortaleza, v.46, n.1, p.43-67, 2015 c.

Graffiti, escritos urbanos entre a cidade material e digital: o que anda a dizer Lisboa? In: SILVA, I.; FRANGELLA, S.; ABOIM, S.; VIEGAS, S. (Org.) Ciências Sociais Cruzadas entre Portugal e o Brasil: trajetos e investigações no ICS. Lisboa: Imprensa de Ciências Sociais, 2015d. p. 119-132.

. Conexões entre artes de rua, criatividade e profissões: circuitos e criações de Tamara Alves. Horizontes Antropológicos, Porto Alegre, ano 25, n.55, p.153-77, set./ dez. 2019.

Mar, 2020.

"Não ao Não" - um estudo sobre a geração N. Fortaleza: Instituto Dragão do

DIÓGENES, G.; CHAGAS, J. O ruidoso silêncio da pixação: linguagens e artes de rua. Nava, Juiz de Fora, v.1, n.2, p.304-30, jan./jun. 2016.

DIÓGENES, G.; SÁ, L. Juventude e segurança pública: dissonâncias e ressonâncias. In: PAPA, F. de C.; FREITAS, M. V. Juventude em pauta: políticas públicas no Brasil. São Paulo; Petrópolis: Ação Educativa; Fundação Friedrich Ebert Stiftung, 2011.

FLUSSER, V. A escrita. São Paulo: Annablume, 2010.

Gestos. São Paulo: Annablume, 2014.

FOUCAULT, M. Os anormais. São Paulo: Martins Fontes, 2002.

GENARO, E. de. Harun Farocki: operador de mídias. Matrizes, São Paulo, v.10, n.2, p.115-134, maio/ago. 2016.

HANNERZ, U. Explorando a cidade: em busca de uma antropologia urbana. Petrópolis: Vozes, 2015.

INGOLD, T. Trazendo as coisas de volta à vida: emaranhados criativos num mundo de materiais. Horizontes Antropológicos, Porto Alegre, v.18, n.37, p.25-44, jan./jun. 2012. Vozes, 2015.

Estar vivo: ensaios sobre movimento, conhecimento e descrição. Petrópolis:

MISSE, M. (Org.) Acusados e acusadores: estudos sobre ofensas, acusações e incriminações. Rio de Janeiro: Revan; Faperj, 2008.

PAIS, J. M. Culturas Juvenis. Lisboa: Imprensa Nacional Casa da Moeda, 2003.

Apresentação In: ALMEIDA, M. I. M. de; PAIS, J. M. (Org.) Criatividade, juventude e novos horizontes profissionais. Rio de Janeiro: Zahar, 2012. p.143-85.

A captação do social e as armadilhas do método: aprendendo com Ruth Cardoso e seu jeito de ser. Análise Social, Lisboa, v.222, n.1, p.120-38, 2017.

PAIVA, L. S. F. "Aqui não tem gangue, tem facção": as transformações sociais do crime em Fortaleza, Brasil. Caderno CRH, Salvador, v.32, n.85, p.165-84, jan./abr. 2019.

PIÚBA, F. A transpoesia dos meninos e meninas dos saraus. Apresentação. In: Rumapoemas de saraus. Fortaleza: Secretaria de Cultura do Estado do Ceará, 2019.

PONTE, S. R. Fortaleza Belle Époque: a disciplinarização da pobreza. Fortaleza: Fundação Demócrito Rocha, 1993. 
SARAIVA, A. Orélio Cearense - Dicionário Romanceado e Ilustrado de Termos e Expressões do Palavreado do Ceará. Fortaleza: Orélio Cearense, 2002.

SILVA, R. A palavra aberta. In: Ruma-poemas de saraus. Fortaleza: Secretaria de Cultura do Estado do Ceará, 2019.

SILVA, R.; DE FREITAS, G. J. Práticas poéticas: juventude, violência e insegurança em Fortaleza. Tensões Mundiais, Fortaleza, v.14, n.26, p.129-55, 2018.

SPOSITO, M. A sociabilidade juvenil e a rua: novos conflitos e ação coletiva na cidade. Tempo Social, São Paulo, v.5, n.1/2, p.161-78, 1996.

RESUMO - Embora estudos apontem, cada vez mais, a ampliação de índices da denominada juventude "nem, nem, nem" (nem estuda, nem trabalha, nem pretende voltar a trabalhar e estudar) e a intensificação de sua inserção em facções e rotas do tráfico na paisagem das metrópoles, paradoxalmente observa-se um incremento de experiências juvenis criativas que emergem da vivência das ruas e da formação de coletivos de periferia. Práticas culturais de origem diversa atravessam lugares materiais e digitais, mobilizando entre jovens múltiplos fazeres: organização de saraus, produções audiovisuais realizadas por meio de celulares, formação de coletivos de arte, inserção em grupos de teatros de rua, dentre outros. Contrariando caminhos normativos mediados pela via institucional escola/trabalho e sob um efeito de "táticas desviacionistas" (De Certeau), essas juventudes parecem condensar signos inventariados pelas mídias com repertórios concernentes a estéticas, jeitos e linguagens pactuados nas culturas de rua. Este artigo pretende, assim, discorrer acerca da experiência exemplar de produção do seriado La Casa d'uz Vetin, produzido por influenciadores digitais da periferia, destacando novos diagramas de criatividade e práticas emblemáticas das juventudes contemporâneas.

PALAVRAS-CHAVE: Juventude, Arte, Redes sociais digitais, Criação, Cultura de rua.

ABSTRACT - Although studies increasingly show the growth of the so-called "neither, nor, nor" youths (who neither study, nor work, nor intend to go back to work and study), and their greater insertion in drug trafficking factions and routes in the metropolitan landscape, there is, paradoxically, a rise in creative youth experiences emerging from street life itself and from the formation of collectives in the periphery of cities. Cultural practices of different origins crisscross the material and digital spheres, mobilizing youth to multiple actions, such as organizing soirees, making videos and music on smartphones, creating art collectives, and participating in street theater groups, among others. Going against the grain of normative paths mediated by the institutional route of school/work and under the influence of "deviation tactics" (De Certeau, 1994), these youths seem to condense signs inventoried by the media with repertoires concerning the agreed-upon aesthetics, manners and languages of street cultures. This article intends to discuss the exemplary production experience of the series La Casa Dúz Vetin, produced by digital influencers from the urban periphery, highlighting new diagrams of creativity and emblematic practices of contemporary youth.

KEYWORDS: Youth, Art, Digital social networks, Creation, Street culture.

Glória Diógenes é professora titular do Programa de Pós-Graduação em Sociologia da Universidade Federal do Ceará (UFC), bolsista de Produtividade do CNPq e coordenadora do Laboratório das Artes e das Juventudes (Lajus).

@ - gloriadiogenes@gmail.com / http://orcid.org/0000-0002-7494-8553. 
Recebido em 28.5.2020 e aceito em 19.6.2020.

I Programa de Pós-Graduação em Sociologia, Universidade Federal do Ceará, Fortaleza, Ceará, Brasil. 
